\title{
Evaluating performance of soil water movement and groundwater recharge in an irrigated agricultural area of Yinchuan Plain, China
}

\author{
Lihu Yang ${ }^{1}$ and XF Song ${ }^{2}$ \\ ${ }^{1}$ Institute of Geographic Sciences and Natural Resources Research, Chinese Academy of \\ Sciences \\ ${ }^{2}$ Institute of Geographic Sciences and Natural Resources Research Chinese Academy of \\ Sciences
}

October 4, 2021

\begin{abstract}
Surface irrigation has been predominantly used for field crops in agriculture area to boost agricultural yields and outputs, however, this may also raise groundwater tables, salinize soils and reduce water quality due to poor irrigation management. Therefore, it is essential for requiring a better understanding of the hydrologic mechanisms related to soil water fluxes (e.g., evaporation, transpiration, infiltration, deep percolation and groundwater capillary rise) by surface irrigation. This study investigated the impact of surface irrigation on soil water movement and recharge to groundwater in the Yellow River irrigation area of Yinchuan Plain, China. Combining comprehensive filed observation and stable isotopic techniques, we described the soil water mechanism under two land covers (bare ground or maize) in 2019 and 2020. The soil depths affected by precipitation infiltration and evaporation were mainly $0-50 \mathrm{~cm}$, while the soil influenced by irrigation was the entire profile in the mode of piston flow. According to soil water potential variation from 70 to $100 \mathrm{~cm}$, we conclude that the maize root took up the soil water up to the depth of $100 \mathrm{~cm}$ during the tasseling period. The infiltration and capillary rise in 2020 were similar with those in 2019. However, the total deep percolation was $156.6 \mathrm{~mm}$ in 2020 which was smaller than that in 2019 because of the maize root water uptake. The leakage of ditch was the major recharge resource of groundwater for the fast water table rise. This study is critical for agricultural water management to improve irrigation efficiency and water use efficiency in arid regions.
\end{abstract}

Evaluating performance of soil water movement and groundwater recharge in an irrigated agricultural area of Yinchuan Plain, China

Lihu Yang ${ }^{1,2} 11^{*}$ Correspondence to: Lihu Yang, Key Laboratory of Water Cycle and Related Land Surface Processes, Institute of Geographic Sciences and Natural Resources Research, Chinese Academy of Sciences, , Datun Road, Chaoyang District, Beijing 100101, People's Republic of China Email:yanglihu@igsnrr.ac.cn, Xianfang Song ${ }^{1,2}$

Key Laboratory of Water Cycle and Related Land Surface Processes, Institute of Geographic Sciences and Natural Resources Research, Chinese Academy of Sciences, , Datun Road, Chaoyang District, Beijing 100101, People's Republic of China

University of Chinese Academy of Sciences, 100049, Beijing, People's Republic of China

Abstract:Surface irrigation has been predominantly used for field crops in agriculture area to boost agricultural yields and outputs, however, this may also raise groundwater tables, salinize soils and reduce water quality due to poor irrigation management. Therefore, it is essential for requiring a better understanding of the hydrologic mechanisms related to soil water fluxes (e.g., evaporation, transpiration, infiltration, deep 
percolation and groundwater capillary rise) by surface irrigation. This study investigated the impact of surface irrigation on soil water movement and recharge to groundwater in the Yellow River irrigation area of Yinchuan Plain, China. Combining comprehensive filed observation and stable isotopic techniques, we described the soil water mechanism under two land covers (bare ground or maize) in 2019 and 2020. The soil depths affected by precipitation infiltration and evaporation were mainly 0-50 cm, while the soil influenced by irrigation was the entire profile in the mode of piston flow. According to soil water potential variation from 70 to $100 \mathrm{~cm}$, we conclude that the maize root took up the soil water up to the depth of $100 \mathrm{~cm}$ during the tasseling period. The infiltration and capillary rise in 2020 were similar with those in 2019. However, the total deep percolation was $156.6 \mathrm{~mm}$ in 2020 which was smaller than that in 2019 because of the maize root water uptake. The leakage of ditch was the major recharge resource of groundwater for the fast water table rise. This study is critical for agricultural water management to improve irrigation efficiency and water use efficiency in arid regions.

Key words: Soil water movement, Groundwater recharge, Comprehensive filed observation, Stable isotopes, Irrigated agricultural area

\section{Introduction}

Surface irrigation has been predominantly used for field crops in agriculture area in China, and other arid and semi-arid regions of world (Khan et al., 2014; Lecina et al., 2011; Li et al., 2020; Merchán et al., 2013; Nagaraj, 1999; Wu et al., 2016). According to the estimations, at least 300 million hectares are irrigated worldwide today, about more than five times in the early twentieth century (FAO, 2011). Although irrigation has helped boost agricultural yields and outputs, in many arid and semi-arid regions, surface water from the river diversion has markedly raised groundwater tables, salinized soils and reduced water quality due to poor irrigation management (Ren et al., 2016; Scanlon et al., 2007). Therefore, it is essential for better understanding the hydrologic mechanisms related to soil water fluxes (e.g., evaporation, transpiration, infiltration, and deep percolation) by surface irrigation.

Water infiltration into the soil is the principal means for replenishment of moisture and recharge to groundwater. Previous studies suggested that moisture movement in the unsaturated zone was controlled by the rate and duration of irrigation, the antecedent soil moisture conditions, the water table depth, the vegetation cover and the soil type (Dahan et al., 2007; Kumar, 2003; Min et al., 2018; Ochoa et al., 2009; Teshome et al., 2018; Wang et al., 2012; Zheng et al., 2019). Therefore, surface irrigation has a strong influence on soil water movement and groundwater recharge. This kind of scenario is typically found in the Yellow River irrigation area of Yinchuan Plain, China. In this agricultural area, surface irrigation often exceeds plant consumptive demand and excess irrigation percolates below the root zone and ultimately joins the shallow aquifer (Qian et al., 2012). There are increasing water problems in this region, including the change in the water table (Cui and Li, 2012; Wei, 2013), soil and groundwater salinization (Zhang et al., 2009; Zhang et al., 2015), the contamination of water by nitrate derived from nitrogen fertilization (Jing et al., 2015; Ke et al., 2014). However, little interest has been paid to the movement of the percolating water and seasonal recharge to groundwater in different land covers. Thus, there is still a need to investigate the dynamics of soil water regime under surface irrigation.

When the importance of the soil water movement in an agriculture ecosystem is considered, it is obvious that one measurement is not appropriate to reflect the vertical profiles. Therefore, a variety of methods to be taken are of great consequence for knowing how soil water changes through the profile and recharges to groundwater in time. Some of these methods involve measurements of soil matric potential (SMP) and soil water content (SWC), changes in the groundwater level, and the use of isotopes to reveal water flux. The SMP drives liquid water movement in the soil. It has been a useful way to describe water movement (Scanlon and Goldsmith, 1997; Scanlon et al., 2005), to calculate evaporation (Liu and Zhan, 2017; Wang et al., 2012), and to study the effects of irrigation on salt leaching (Wang et al., 2019) in GroundwaterSoil-Plant-Atmosphere-Continuum system. The SWC measurement in the unsaturated zone is a common 
method for quantifying soil water recharge (Ochoa et al., 2009), providing useful information on effects of land use changes (Scanlon et al., 2007) and estimating infiltration process and deep percolation (Dahan et al., 2009; Dahan et al., 2007; Gutiérrez-Jurado et al., 2017; Ochoa et al., 2007). Additionally, isotopes tracers can extend our understanding of evaporation rates (Allison and Barnes, 1983; Barnes and Allison, 1988; Mahendrappa et al., 1966; Robertson and Gazis, 2006), the extent of soil water recharge (Garvelmann et al., 2012; Sprenger et al., 2018), residence times of water along a soil profile (Gazis and Feng, 2004), the infiltration and groundwater recharge (Bengtsson et al., 1987; Song et al., 2009; Tan et al., 2017; Wang et al., 2012), root water uptake patterns (Dawson and Ehleringer, 1991; Ma and Song, 2016; Rothfuss and Javaux, 2017; Wang et al., 2010; Zhao et al., 2018). In summary, the combined physical and isotopic techniques have been proven useful in investigating vertical water movement in the unsaturated zone and identifying the recharge mechanism to groundwater.

In this study, a time series of precipitation, SMP, SWC, water table depth with stable isotope tracers $\left(\delta^{18} \mathrm{O}\right.$ and $\delta \mathrm{D}$ ) was intensively collected in the Yellow River irrigation area of Yinchuan plain, China (Fig. 1). The objectives of this work are therefore to: (1) describe the different characteristics of soil water movement in the vegetation season under two land covers (bare ground or maize), (2) assess the impacts of infiltration from precipitation or surface irrigation on soil water, (3) estimate the soil water storage change and recharge to groundwater. These analyses are also important to policy makers, particularly in water scarcity contexts when changes in water management are planned to reduce water use in farmland and restrain the rise of groundwater level in the irrigation area.

\section{Material and Methods}

\section{Study site}

The study site lies in the Yellow River irrigation area of Yongning County which is located in the middle of the Yinchuan Plain (Fig. 1). The climatic characterization was carried out using the 1951-2020 monitoring data series from National Meteorological Information Center at Yinchuan Station (20km from the study site). According to such data, the climate in this region is semi-arid. The annual average temperature is $9.2^{\circ} \mathrm{C}$, with a wide both daily and seasonal fluctuation. The precipitation is unevenly distributed throughout the year. The least precipitation occurs during winter and the most rain falls from June to September which accounts for $70.6 \%$ of the mean annual precipitation $(196 \mathrm{~mm})$. The max monthly precipitation is $148.7 \mathrm{~mm}$, mainly as light rain and moderate rain. The mean annual potential evaporation is $1595 \mathrm{~mm}$ with a strong seasonal dynamic ranging from about $32 \mathrm{~mm}$ per month in winter to up to $238 \mathrm{~mm}$ per month in summer. Mean relative humidity during these seasons varied between 31.6 and 62.7 percent. There are 144-159 frost-free days and $2888 \mathrm{~h}$ of sunshine per year.

The Yellow River runs through the area from south to north, so water used for irrigation is diverted from the Yellow River. The Hanyan Ditch and Huinong Ditch are the main ditches in the irrigation region. The traditional surface irrigation has been widely implemented for more than 60 years. In recent years, the demand for irrigated agriculture is increasing due to climate change and population growth. Maize, wheat, soybean and some vegetables are the main crops. Owing to a large amount of water from surface irrigation, groundwater is shallow and the depth to water table annually varies from 2.3 to $4.3 \mathrm{~m}$.

\section{Experimental design}

The experiments were conducted at plot 2 of Guanqiao farm from April 2019 to December 2020. In order to assess the different land covers on the soil water movement under irrigation or precipitation, the plot 2 was with bare ground surface in 2019 and planted with maize between 7 May and 20 September, 2020. The plot 1 was planted with maize both in 2019 and 2020. The irrigation schedule in plot 1 was implemented same as that in plot 2. The irrigation was carried out during the maize growing season (May to September) and 
post-harvest autumn ( 8 November) to maintain the soil water. The surface irrigation date was 1 May, 25 May, 2 July, 14 July, 3 August, 16August, 30 August, 8 November in 2019 and 25 May , 5 June, 6 July, 1 August in 2020 (Fig. 2b). The field was flood-irrigated with water diverted from the Hanyan Ditch into a $50 \mathrm{~cm}$ wide open channel (Fig. 1). The maize growing season can be divided into sowing (from 7 to 18 May), seedling (from 19 May to 3 June), jointing (from 4 to 10 July), tasseling (from 11July to 10 August), filling (from 11August to 5 September) and maturity (from 6 to 18 September) stages.

A test pit (1.0 m wide by $1.6 \mathrm{~m}$ long with $2.7 \mathrm{~m}$ depth) was excavated in the plot 2 adjacent to the north edge for soil characterization and installation of soil water sensors, automatic tensiometers and suction lysimeters. In addition, the experimental well and rain gauge were also installed inside of the plot 2. The schematic of plot layout is presented in Fig. 1.

\section{Field monitoring and sampling}

To measure soil water variations in the soil layer, a set of measurement systems was installed in the pit west, east and north wall in September 2018 (Fig. 1). To ensure stabilization between the probes and the surrounding soil, only data between April 2019 and October 2020 were analyzed. The SWC was measured by means of the Time Domain Reflectometry (TDR) technique (TDR-310S, Acclima, USA). The SMP was measured using water-filled hydraulic tensiometer (Yang et al., 2018; Yang et al., 2014). The electronic pressure sensor near the top was installed to measure the force required to remove water from the soil. A set of eight probes of each parameter were horizontally installed at depths of 20,30,50,70,100, 150, 200 and $270 \mathrm{~cm}$. The groundwater level sensor was fixed to measure the distance between the ground and the water table. The rain gauge was the tipping bucket rain gauge type (SL3-1, Shanghai Meteorological Instrument Factory Co., Ltd., China) to monitor the rainfall. All the data were automatically recorded at 5-min intervals and averaged every 30 min by data logger (CR10X, Campbell Scientific, Inc., USA).

Rain water was collected by a rain collector near the rain gauges. After each rainfall event, rainwater was collected and immediately transferred to a bottle and then sealed and stored. Soil water was sampled after each rainfall or irrigation event at the depth same as that of sensors (Yang et al., 2018), using a suction lysimeter designed by Institute of Geographic Sciences and Natural Resources Research, Chinese Academy of Sciences (IGSNRR, CAS), which was composed of a Teflon pipe and porous ceramic tube. A vacuum pump of about $-0.8 \mathrm{MPa}$ was applied to the suction lysimeter for $12 \mathrm{~h}$ of equilibrium to collect soil water. Irrigation water and ground water was sampled directly from ditch at irrigation event and pump discharge very month, respectively.

Soil samples, obtained at an interval of $20 \mathrm{~cm}$ from the $0-270 \mathrm{~cm}$ depth in the test pit, were measured for particle size analysis using a Mastersizer 2000 (Malvern Instruments, Malvern, UK) in the laboratory. According to the International Classification System, the soil texture at 0 $130 \mathrm{~cm}$ depth is loam and silty loam at $150^{\sim} 270 \mathrm{~cm}$ depth. The bulk density ranged from 1.63 to $1.72 \mathrm{~g} \mathrm{~cm}^{-3}$ for the soil (Table 1 ).

\section{Laboratory experiment}

All the water samples were filtered through $0.2 \mu \mathrm{m}$ filters before isotope analysis and analyzed in IGSNRR, CAS. The stable isotopes of water samples $\left(\delta \mathrm{D}, \delta^{18} \mathrm{O}\right)$ were analyzed using off axis integrated-cavity output laser spectroscopy (Model DLT-100; Los Gatos Research Inc.). All samples were normalized to internal laboratory water standards that were previously calibrated relative to the Vienna Standard Mean Ocean Water (VSMOW, 0 per thousand deviations from the VSMOW with analytical precisions of \pm 1.0

\section{Calculation methods}

To investigate the soil moisture depletion and incomplete recharge, we calculate the daily evapotranspiration rates using a simplified water balance equation (Jipp et al., 1998): 
$E T=W+P+I-D_{p}+D_{r}(1)$

Where ET is evapotranspiration, $W$ is the change in soil moisture storage in the soil profile (to $270 \mathrm{~cm}$ ) between successive field measurements, $P$ is precipitation, $I$ is irrigation, $D_{p}$ is deep percolation below the root zone, $D_{r}$ is capillary rise from shallow water table over the same period. All variables are expressed in $\mathrm{mm} / \mathrm{d}$.

Vertical water flux is calculated using Darcy's equation with estimates of the soil water potential (SWP) gradient and unsaturated hydraulic conductivity.

Darcy's law (downward positive) is:

$D=-K(h)\left(\frac{\partial \psi}{\partial z}\right)(2)$

Where $D$ is the soil water flux $(\mathrm{mm} / \mathrm{d})$, for which a negative value represents soil moisture upward moving $\left(D_{r}\right)$ and a positive value represents soil moisture downward moving $\left(D_{p}\right), K(h)$ is the unsaturated hydraulic conductivity $(\mathrm{mm} / \mathrm{d})$ at the depth of $(\mathrm{cm})$ and $\psi$ is the soil water potential $\left(\mathrm{cm} \mathrm{H}_{2} \mathrm{O}\right)$ which is calculated by soil matric potential plus gravity potential. The zero point for gravity potential is defined at the ground surface.

To calculate deep percolation $\left(D_{p}\right)$ or capillary rise $\left(D_{r}\right)$ between 200 and $270 \mathrm{~cm}$, equation $(2)$ can be written in a differential scheme as follows:

$D_{p}$ or $D_{r}=D=-\sqrt{K_{200} K_{270}}\left(\frac{\psi_{200}-\psi_{270}}{70}\right)(3)$

Where $D_{p}$ is the positive value of $D$ and $D_{r}$ is the negative value of $D, K_{200}$ and $K_{270}$ are the unsaturated hydraulic conductivity at 200 and $270 \mathrm{~cm}$ depth $(\mathrm{mm} / \mathrm{d})$, respectively. $\psi_{200}$ and $\psi_{270}$ are the SWP at 200 and $270 \mathrm{~cm}$ depth $\left(\mathrm{cm} \mathrm{H}_{2} \mathrm{O}\right)$, respectively.

The van Genuchten model (Van Genuchten, 1980) is used to calculate the unsaturated hydraulic conductivity in the vadose zone.

The VG model for moisture retention curve is:

$\theta(S)=\theta_{r}+\left(\theta_{s}-\theta_{r}\right)\left[1+|\partial S|^{n}\right]^{-m}(4)$

Where $\theta(S)$ is SWC $\left(\mathrm{cm}^{3} \mathrm{~cm}^{-3}\right), \vartheta_{\mathrm{s}}$ is the saturated water content $\left(\mathrm{cm}^{3} \mathrm{~cm}^{-3}\right), \vartheta_{\mathrm{r}}$ is the soil residual content $\left(\mathrm{cm}^{3} \mathrm{~cm}^{-3}\right), n$ and $m$ are the shape parameters of soil water characteristic, $m=1-1 / n, 0<m<1$. According to the measurement of the water retention curve, the VG model was fitted by Retention Curve (RETC) Computer Program.

\section{Results}

\section{Precipitation and water table}

The total rainfall from April to October in 2019 and 2020 was 160.8 and $179.2 \mathrm{~mm}$, respectively. During the 2 years, the number of days with rainfall larger than $1 \mathrm{~mm}$ was 26 , and 24 days, and the maximum daily rainfall was 25.7, and $19.9 \mathrm{~mm}$ (Fig. 2a). The maximum monthly rain was in July and August, which accounts for $55 \%$ and $45 \%$ of annual precipitation. In general, the rainfall was characterized by small rain and moderate rain.

During the measurement period, water table depth (WTD) ranged from 233 to $436 \mathrm{~cm}$ (Fig. 2b). The minimum depth to water occurred in May 2020, whereas, the maximum occurred in July 2019. In general, during the long dry period between the beginning of winter and early summer, WTD continuously increased to approximate $434 \mathrm{~cm}$. In the rainy season from May to July, WTD decreased due to the irrigation or precipitation. The variation of WTD was primarily a response to irrigation and local ET. The highest peak 
water level was observed after the irrigation event of 2 July 2019. In addition, the maximum increase (118 $\mathrm{cm}$ ) of WTD appeared in 8 November 2019 due to the irrigation water percolation to groundwater. This is illustrated by data for the irrigation events of 2 July and 8 November 2019 . WTD was $348 \mathrm{~cm}$ before the 2 July irrigation event and $428 \mathrm{~cm}$ before the 8 November irrigation event (Fig. 2b). The minimum WTD reached $234 \mathrm{~cm}$ and $310 \mathrm{~cm}$, respectively. After irrigation, the water table fell fast to the level at the beginning of irrigation and then slowly declined because of evaporation and plant water uptake.

\section{Soil water content (SWC)}

The mean, standard deviation (SD), and coefficients of variation (CV) values of the soil water content at different depth were used to represent the spatial-temporal variability in soil moisture (Table 2). During the observation period, the mean SWC ranged from 0.247 to 0.285 for the $0-50 \mathrm{~cm}$ soil layer and 0.275 to 0.371 for the 50-270cm soil layer, respectively. The mean SWC increased with soil depth, reaching a maximum at $50 \mathrm{~cm}$. After an increase of water content with depth down from surface to $50 \mathrm{~cm}$, another increase with depth could be also observed at about 50-270 cm depth. High soil moisture SD value (0.050) and CV value (0.203) were mainly detected in the shallow layers $(0-20 \mathrm{~cm})$, and these values decreased with increased soil depth. Although both variables decreased along the profile, the decrease in $\mathrm{CV}$ was much quicker than that in $\mathrm{SD}$, from 0.203 to 0.014 and 0.050 to 0.005 , respectively.

The statistical data showed that the SWC varied significantly at depth of $20-50 \mathrm{~cm}$, but not at the deeper soil layer $(150-270 \mathrm{~cm})$ during the observation period. Fig. 3(a,b) shows the dynamic changes of SWCs with time at different depths. The SWC had apparent seasonal changes and was fluctuant with precipitation and irrigation processes. According to these processes, the whole observation period could be divided into three stages: change period of gains and losses (from April to September), relatively stable period (from October to mid-November), period of slow decline after autumn irrigation (from mid-November to March) at 20,30 and $50 \mathrm{~cm}$.

The first period was an obvious gain and loss period, in which the SWC increased greatly after precipitation or irrigation and decreased slowly because of percolation and evapotranspiration. The total rainfall was 59.2 $\mathrm{mm}$ from 25 to 27 June, 2019 and $39.8 \mathrm{~mm}$ on from 29 to 30 August, 2020. The SWC at $30 \mathrm{~cm}$ increased to approximately 0.358 and 0.341 , respectively. The SWC sharply increased at depth of $20-50 \mathrm{~cm}$, from about 0.196 to 0.376 after irrigation on July 14, 2019 and from about 0.146 to 0.364 after irrigation on July 6 , 2020. However, the SWC recession at soil depths above $70 \mathrm{~cm}$ in 2020 was higher than that in 2019. This was mainly due to stronger evaporation and water use in 2020, when the plot 1 was cropped with maize. The SWC fluctuated with a variation of 0.55 from October to mid-November due to little precipitation and non-irrigation, which could be considered a relatively stable period. Lastly, the SWC decreased gradually from mid-November after autumn irrigation to March of the next year, which could be considered a losing period.

\section{Soil water potential(SWP)}

Fig. 3(c,d) shows the SWP dynamics at different depths during the observed period in 2019 and 2020. The mean values of SWP at eight different depths of soil layers were between -115.7 and $-219.5 \mathrm{~cm}_{2} \mathrm{O}$ in 2019 and between -151.1 and $-236.2 \mathrm{~cm} \mathrm{H}_{2} \mathrm{O}$ in 2020 . The maximum value was $-23.7 \mathrm{~cm} \mathrm{H}_{2} \mathrm{O}$ at $20 \mathrm{~cm}$ layer in 2019 and $-21.4 \mathrm{~cm} \mathrm{H}_{2} \mathrm{O}$ at $20 \mathrm{~cm}$ layer in 2020 . The minimum value was $-269.8 \mathrm{~cm} \mathrm{H}_{2} \mathrm{O}$ at $270 \mathrm{~cm}$ layer in 2019 and $-438.5 \mathrm{~cm} \mathrm{H}_{2} \mathrm{O}$ at $70 \mathrm{~cm}$ layer in 2020 . This difference was probably caused by the maize of which roots mainly extracted water from the $70 \mathrm{~cm}$ soil. The SWPs at 20,30 and $50 \mathrm{~cm}$ ranged from -23.7 to -222.15 $\mathrm{cm} \mathrm{H}_{2} \mathrm{O}$ in 2019 and from -21.3 to $402.1 \mathrm{~cm} \mathrm{H}_{2} \mathrm{O}$ in 2020, with greater oscillation due to the evaporation and irrigation between May and September. In October, because no irrigation was performed, the SWPs at 20-50 cm decreased with time. The SWPs at 200 and $270 \mathrm{~cm}$, close to the groundwater capillary zone, were affected by the water table fluctuation. With increasing water table during irrigation periods, the SMPs at $270 \mathrm{~cm}$ decreased with time and were even close to 0. 
The statistics of SWP gradients are presented in Table 3. The SWP gradients were almost negative in 2019. The soil water displayed an upward trend of movement with the mostly positive SWP gradients at $20-30 \mathrm{~cm}, 70-100 \mathrm{~cm}$ and $150-200 \mathrm{~cm}$ depth ranges in 2020 . When evaporation continues after the precipitation or irrigation, the soil water in the upper part moved upwards to the soil surface (KHALIL et al., 2003; Li et al., 1990). As the SWP gradients decrease with increasing depth, at some level it is no longer large enough to drive the soil water upward and the flux is essentially zero. This level is known as the zero flux plane (ZFP), below which the soil water at lower depth moved downwards towards the water table due to gravity (Sadeghi et al. 1985). Fig 4 shows an example of the SWCs and SWPs at various depths before and after the precipitation or irrigation event in 2019 and 2020. The SWP profile of June 28, 2019 showed that ZFP was at $30 \mathrm{~cm}$ (Fig. 4b). By June 30, the ZFP has passed below the $50 \mathrm{~cm}$. After the irrigation on August 4, 2019, the ZFP was at $20 \mathrm{~cm}$ depth on the first day, then extended from 30 to $70 \mathrm{~cm}$ in the next four days, and stabilized at $70 \mathrm{~cm}$ on the last three days (Fig. 4d). The ZFP was more rapidly developed after irrigation on August 2020 than irrigation on August 2019, which suggests that the roots take up more soil water (Fig. 4d, h).

\section{Isotopic composition of water}

The $\delta^{18} \mathrm{O}$ and $\delta \mathrm{D}$ of precipitation, irrigation water, soil water and groundwater are presented in Fig. 5 and table 4. In total, seventeen precipitation samples were collected from April to December in 2019 and 2020. The isotopi $c$ values of precipitation were highly variable. In 2019 , The $\delta \mathrm{D}\left(\delta^{18} \mathrm{O}\right)$ in precipitation ranged from -63.5 (-10.26) to -18.1 (-4.5) average value of -43.6 (-6.91) (2.12) -51.0 (-6.87) to -1.9 (-0.09) and $\mathrm{SD}$ of $17.7(2.49) \delta^{18} \mathrm{O}$ were observed during heavy and continuous (e.g., June 25-27, 2019) rainfall events, indicating a strong rainout effect (Clark and Fritz, 1997; Liu et al., 2011). The local meteoric water line (LMWL) was established as $\delta \mathrm{D}=7.11 \delta^{18} \mathrm{O}+5.14\left(R^{2}=0.91\right)$. The slope of the LMWL was similar with that of $\delta \mathrm{D}=7.21 \delta^{18} \mathrm{O}+5.50\left(R^{2}=0.96\right)$, based on the monthly data from IAEA collected at Yinchuan station between 1988 and 2000 .

The irrigation water and groundwater $\delta \mathrm{D}$ and $\delta^{18} \mathrm{O}$ varied little in the range of -68.1 to $-71.8-72.6$ to $-64.5 \delta^{18} \mathrm{O}$ of the two water bodies were very similar, which implies that the groundwater was mainly recharged by irrigation water.

The range of $\delta \mathrm{D}$ values in soil water were between -75.0 and -24.1 with a mean value of $-61.4 \delta^{18} \mathrm{O}$ ranged from -11.4 to -4.63 of -8.74 at 20,30 and $50 \mathrm{~cm}$ were more variable. The mean values of $\delta \mathrm{D}$ and $\delta^{18} \mathrm{O}$ were approximately -62.6 and minimum values appeared at $20 \mathrm{~cm}$ in June and in July, respectively. This variation was mainly caused by kinetic fractionation of evaporation and infiltration of precipitation or irrigation. The values for the deeper soil layers were relatively stable with an average of $-60.5 \delta \mathrm{D}$ and -8.59 compositions of the soil water samples in 2020, they ranged from -72.2 to -52.0 for $\delta^{18} \mathrm{O}$, respectively. The isotopic compositions of soil water at 20,30 and $50 \mathrm{~cm}$ were closer to that of irrigation water compared to that at other depths. The isotopic compositions at $270 \mathrm{~cm}$ were more enriched relative to the stable isotopes of groundwater.

The evaporation line of soil water (ELSW) equation was $\delta \mathrm{D}=4.27 \delta^{18} \mathrm{O}-25.19\left(R^{2}=0.41\right)$. The stable isotopes of soil water were scattered and the slope was lower compared to the LMWL, indicating that the $\delta$ $\mathrm{D}$ and $\delta{ }^{18} \mathrm{O}$ in soil water were mainly influenced by mixing with precipitation or irrigation and undergoing evaporation.

\section{Discussion}

\section{Impact of infiltration from precipitation or flood irrigation on soil water}

The soil water is significantly influenced by the precipitation, evapotranspiration, and infiltration, showing that the SWPs and SWCs increase during the irrigation / precipitation period and decrease during the nonirrigation period (Fig. 3 and 4). The SWCs and SWPs before and after the $59.2 \mathrm{~mm}$ large rain event during 
the period 25-27 June 2019, the $68 \mathrm{~mm}$ irrigation on 3 August 2019, the $137 \mathrm{~mm}$ irrigation on 6 July 2020 and the $122 \mathrm{~m}$ irrigation on 1 August 2020, were used to evaluate the process of precipitation /irrigation infiltration and soil water movement (Fig. 4).

At the surface layer $(0-50 \mathrm{~cm})$, it was generally found that the SWCs increased from the range of 0.18-0.33 to the range of $0.25-0.37$ after the large rain. The average SWP at $0-50 \mathrm{~cm}$ increased from -120 to $-56 \mathrm{~cm}$ and the values below a depth of $50 \mathrm{~cm}$ were relatively stable. Similarly, soil water isotopic compositions were depleted in $\delta \mathrm{D}$ and $\delta^{18} \mathrm{O}$ in soil layers above $50 \mathrm{~cm}$ in response to the large rainfall event. The average value $\delta \mathrm{D}$ at $0-50 \mathrm{~cm}$ ranged from -37.8 to -53.4 respectively. Main changes in the SWCs, SWPs and isotopic compositions at $0-50 \mathrm{~cm}$ depth during precipitation and non-precipitation periods was greater than those at other depths. Therefore, it can be identified that the soil at 0-50 depth with bare ground surface is mainly influenced by precipitation infiltration and evaporation to a greater extent compared with below. These results correspond to the findings of Wang et al., (2012), who found that the depth mainly affected precipitation infiltration and evaporation was $0-50 \mathrm{~cm}$ in Yuncheng, Shanxi Province.

The SWCs exhibited a sharp increase when irrigation began and then decreased rapidly as it was turned off. The increase in SWCs occurred layer by layer from the upper horizons, suggesting piston flow was the dominant mode of irrigation-driven soil water flow. The soil water $\delta \mathrm{D}$ and $\delta^{18} \mathrm{O}$ in 2019 and 2020 had almost the same range as irrigation water, which indicated rapid infiltration of soil water across the entire profile to irrigation (Fig. 4). After 6 days of irrigation, the SWCs at 20 and $30 \mathrm{~cm}$ depth decreased by 0.053 and 0.039 in August, 2019 and 0.058 and 0.032 in August, 2020, respectively. For the same interval of time the SWCs at 70 and $100 \mathrm{~cm}$ depths of soil only decreased by 0.014 and 0.006 in 2019 and by 0.009 and 0.022 in 2020, respectively. These differences may be the fact that water at the top part continued to move down the profile. The middle soil was leaching water to the soil below it but at the same time it was receiving water from the soil above it, which resulted in the slower rates of SWCs decrease at 70 and $100 \mathrm{~cm}$ depth than those at the top part $(20$ and $30 \mathrm{~cm})$. The similar patterns of changes in SWCs were observed in irrigated agricultural field of a desert oasis in Northwest China (Li et al., 2018).

Owing to the root water uptake in 2020, the SWPs variation mainly occurred in the upper $50 \mathrm{~cm}$ layer during the jointing period because of evapotranspiration. The SWPs at 20,30 and $50 \mathrm{~cm}$ showed a remarkable decrease with time, ranging from the average value of $-204.3 \mathrm{~cm} \mathrm{H}_{2} \mathrm{O}$ on 28 June to $-336.5 \mathrm{~cm}_{2} \mathrm{O}$ on 6 July. During the tasseling period, the SWPs at 70 and $100 \mathrm{~cm}$ were found to exhibit abruptly lower values than those on the jointing period. The SWPs of 70 and $100 \mathrm{~cm}$ soil depths continuously decreased with average value from $-213.4 \mathrm{~cm} \mathrm{H}_{2} \mathrm{O}$ on 6 July to $-400.3 \mathrm{~cm} \mathrm{H}_{2} \mathrm{O}$ on 1August. The results indicate that some of the maize root system has reached the depth of $100 \mathrm{~cm}$ during the tasseling periods due to the increased water consumption. The maximum root depth was similar to that in Beijing described in the related research (Ma and Song, 2016).

Since the soil water at 0-50 $\mathrm{cm}$ for bare ground surface is mainly affected by precipitation, evaporation, the SWP and SWC at these depths have relatively major changes with time (Figs. 3 and 4). The isotopic compositions of the soil water samples collected from 20,30 and $50 \mathrm{~cm}$ depths vary more diverse with the isotopic values of rain than those from other depths. Those implied that ordinary rainfall events and even continuous rain with $59.2 \mathrm{~mm}$ rain rarely affected the soil water in the deeper layers.

\section{Estimation of soil water storage change and recharge to groundwater}

For the observation period, the soil water storage, evapotranspiration /soil evaporation, infiltration (irrigation plus precipitation), deep percolation and groundwater capillary rise in the different land cover types between May and September was calculated using the water balance Eq. (1), and the results are presented in Table 5.The soil water storage change differed for bare ground in 2019 and for maize in 2020 about the amount and temporal development. The soil water storage (SWS)in 2019 firstly decreased from 7 may to 11 June (S1 and S2 stage) and then increased from 12 June to 5 September (S3, S4 and S5 stage) and lastly decreased from 6 to 18 September (S6 stage). The increasing SWS may result from the downward movement of the 
soil water from infiltration of irrigation/ precipitation and the depletions of SWS could be due to the soil evaporation. The infiltration was the main water input component. The highest $(183.3 \mathrm{~mm})$ and lowest $(7.8 \mathrm{~mm})$ volumes of water occurred at S5 and S1 stage, respectively. The capillary rise from groundwater accounted for only $2.2 \%$ of the total inputs in the balance, which varied temporally according to groundwater level. In terms of outputs, the deep percolation $(312.0 \mathrm{~mm})$ was the main component throughout the entire study period, accounting for $57.4 \%$ of the total outputs. The lowest value was recorded at S1 stage $(3.1 \mathrm{~mm}$, $0.6 \%$ of outputs), while the highest occurred at $\mathrm{S} 5$ stage $(183.3 \mathrm{~mm}, 24.1 \%$ of outputs). As expected, deep percolation increased with the expansion of infiltration, from $66.1 \mathrm{~mm}$ at $\mathrm{S} 3$ stage to $131.0 \mathrm{~mm}$ at S5 stage. The soil evaporation $(231.2 \mathrm{~mm})$ corresponded to $42.6 \%$ of the outputs in the entire study period of 2019 . Although the highest soil evaporation $(69.3 \mathrm{~mm})$ was recorded at $\mathrm{S} 4$ stage, the infiltration was not largest at this stage. The data shows that the soil evaporation is not only affected by the SWS, but also by the other factors, such as temperature, wind speed etc.

Temporal dynamics of the SWS was different for maize in 2020 compared with bare ground in 2019. Field water balance components over the growing season status was calculated (Table 5). The SWS decreases during the three periods (at the sowing, tasseling, and filling stage) due to the excess of evapotranspiration relative to the irrigation/precipitation infiltration. The largest depletions of the SWS $(-58.1 \mathrm{~mm})$ could be observed at tasseling stage, which is likely caused by increasing maize water use during the growing season. The infiltration and capillary rise were $535.9 \mathrm{~mm}$ and $8.7 \mathrm{~mm}$, respectively, which were similar with that in 2019. However, the highest value of infiltration was $150.1 \mathrm{~mm}$ recorded at seedling stage which was smaller than that at S5 stage in 2019. The total deep percolation was $156.6 \mathrm{~mm}$, accounting for $29.2 \%$ of the total infiltration precipitation or irrigation. The deep percolation was lowest $(3.3 \mathrm{~mm})$ at the sowing stage and highest $(41.4 \mathrm{~mm})$ at tasseling stage. The ET in the maize field was larger than deep percolation, which suggests that the water lost by ET in the irrigated areas was the greatest output component in the water balance. The total ET for maize was $431.3 \mathrm{~mm}$, which was very similar to that found by other researchers (Ren et al., 2016; Xu et al., 2013). In addition, the roots of maize at tasseling stage were mainly distributed in the depth range of $0-100 \mathrm{~cm}$, where soil water consumption intensity was the highest over observation period. Therefore, the maize development and grain yield will consume more soil water.

As already mentioned, the depth of infiltration from precipitation was approximately $50 \mathrm{~cm}$, indicating that the infiltration of precipitation cannot be attributed to groundwater recharge. However, the groundwater level response following surface irrigation was obtained. Combined with the analysis of the water table fluctuations, it can be reasonably concluded that the groundwater may be recharged by the lateral groundwater flow leaked from the ditch and the infiltration of surface irrigation. The fast leakage of ditch resulted in maximal groundwater level response following most irrigations. For example, the water table response occurred on 1 July 2019, with a maximum rise of $16 \mathrm{~cm}$ to the beginning of irrigation (Fig. 2). The water level before the start of irrigation was about $360 \mathrm{~cm}$ below ground level and it was observed that a significant water level rise $(114 \mathrm{~cm})$ started about $22 \mathrm{~h}$ after the end of irrigation. The observed rise rates of the water level are approximately $9.5 \mathrm{~cm} / \mathrm{h}$. However, the small deep percolation was only $30 \mathrm{~mm}$ during the irrigation which is the smallest recharge into groundwater. It can be speculated that the recharge from the leakage of ditch is indeed responsible for the groundwater level rise on this basis.

\section{Conclusions}

The dynamics of soil water movement and recharge to groundwater were studied in the Yellow River irrigation area during the maize growing season by combined physical and isotopic techniques. The results indicate that the soil at 0-50 depth was mainly influenced by precipitation infiltration and evaporation. The entire profile of soil was affected by rapid infiltration from irrigation while the soil water mainly moved downward in the mode of piston flow. The maize root system had reached the depth of $100 \mathrm{~cm}$ during the tasseling periods according to SWPs decrease from 70 to $100 \mathrm{~cm}$. The infiltration and capillary rise were totally $544.6 \mathrm{~mm}$ in 2020, which were similar with that in 2019. However, the total deep percolation(156.6mm) was smaller than 
that in 2019 due to the higher ET. It can be concluded that the leakage of ditch was the major recharge resource of groundwater for the fast water table rise.

The observed temporal variations of soil water in multiple soil layers in two different land covers contribute toward the understanding of the mechanism of soil water and recharge to groundwater in the irrigation area of arid and semi-arid climates. The results provided critical information for soil and water management to improve irrigation efficiency and water use efficiency.

\section{Declaration of Competing Interest}

None.

\section{Acknowledgments}

This research was financially supported by the National Key Research and Development Program of China (2019YFC1804803-2), and the research fund of Ningxia Geological Exploration (Grant No. HZ20170040-I). The authors are thankful to Mr. Zhipeng Zhao, Mr. Yuxue Ma and Mr. Liang Gong from Ningxia Geological Survey Institute for helping with the field work.

\section{References:}

Allison, G.B. and Barnes, C.J., 1983. Estimation of evaporation from non-vegetated surfaces using natural deuterium. Nature, 301(5896): 143-145.

Barnes, C.J. and Allison, G.B., 1988. Tracing of water movement in the unsaturated zone using stable isotopes of hydrogen and oxygen. Journal of Hydrology, 100(1): 143-176.

Bengtsson, L., Saxena, R.K. and Dressie, Z., 1987. Soil water movement estimated from isotope tracers. Hydrological Sciences Journal, 32(4): 497-520.

Clark, I.D. and Fritz, P., 1997. Environmental Isotopes in Hydrogeology. Lewis Publishers, New York.

Cui, X. and Li, G., 2012. The impact of irrigation ditch seepage on the groundwater in Yinchuan plain. Journal of Agriculture Science, 33(04): 47-50 (in Chinese with English abstract).

Dahan, O. et al., 2009. In Situ Monitoring of Water Percolation and Solute Transport Using a Vadose Zone Monitoring System. Vadose Zone Journal, 8: 916-925.

Dahan, O., Shani, Y., Enzel, Y., Yechieli, Y. and Yakirevich, A., 2007. Direct measurements of floodwater infiltration into shallow alluvial aquifers. Journal of Hydrology, 344(3): 157-170.

Dawson, T.E. and Ehleringer, J.R., 1991. Streamside trees that do not use stream water. Nature, 350(6316): 335-337.

FAO, 2011. The state of the world's land and water resources for food and agriculture. Earthscan, Abingdon, UK.

Garvelmann, J., Külls, C. and Weiler, M., 2012. A porewater-based stable isotope approach for the investigation of subsurface hydrological processes. Hydrol. Earth Syst. Sci., 16(2): 631-640.

Gazis, C. and Feng, X., 2004. A stable isotope study of soil water: evidence for mixing and preferential flow paths. Geoderma, 119(1): 97-111.

Gutiérrez-Jurado, Y.K., Fernald, G.A., Guldan, J.S. and Ochoa, G.C., 2017. Surface Water and Groundwater Interactions in Traditionally Irrigated Fields in Northern New Mexico, U.S.A. Water, 9(2). 
Jing, X., Yang, H., Wang, W. and Cao, Y., 2015. Index system methods and safety evaluation on groundwater for drinking. Ecology and Environmental Sciences, 24(01): 90-95(in Chinese with English abstract).

Jipp, P.H., Nepstad, D.C., Cassel, D.K. and de Carvalho, C.R., 1998. Deep Soil Moisture Storage and Transpiration in Forests and Pastures of Seasonally-Dry Amazonia. In: Potential Impacts of Climate Change on Tropical Forest Ecosystems. Springer Netherlands, Dordrecht, pp. 255-272.

Ke, Y., Guo, X., Ji, H., Zhang, W. and Zhao, Y., 2014. The Characteristics of Soil N Accumulation and Movement in Different Farmlands in the Yellow River Irrigation Region of Ningxia, China.Journal of Agriculture Resources and Environment, 31(1): 23-31.

KHALIL, M., SAKAI, M., MIZOGUCHI, M. and MIYAZAKI, T., 2003. Current and prospective applications of Zero Flux Plane (ZFP) method. Journal of the Japanese Society of Soil Physics, 95: 75-90.

Khan, M.R., Voss, C.I., Yu, W. and Michael, H.A., 2014. Water Resources Management in the Ganges Basin: A Comparison of Three Strategies for Conjunctive Use of Groundwater and Surface Water. Water Resources Management, 28(5): 1235-1250.

Kumar, C.P., 2003. Estimation of Ground Water Recharge Using Soil Moisture Balance Approach. Journal of Soil and Water Conservation, Soil Conservation Society of India, Volume 2: pp. 53-58.

Lecina, S., Neale, C.M.U., Merkley, G.P. and Dos Santos, C.A.C., 2011. Irrigation evaluation based on performance analysis and water accounting at the Bear River Irrigation Project (U.S.A.). Agricultural Water Management, 98(9): 1349-1363.

Li, B., Liu, C. and Yang, K., 1990. An application study on the zero flux plane method. Geographical Research(02): 39-50(in Chinese with English abstract).

Li, C. et al., 2020. Effect of irrigation and fertilization regimes on grain yield, water and nitrogen productivity of mulching cultivated maize (Zea mays L.) in the Hetao Irrigation District of China. Agricultural Water Management, 232: 106065.

Li, Z. et al., 2018. Estimation of Evapotranspiration and Other Soil Water Budget Components in an Irrigated Agricultural Field of a Desert Oasis, Using Soil Moisture Measurements. Hydrol. Earth Syst. Sci. Discuss., 2018: 1-17.

Liu, X. et al., 2011. Spatio-temporal variations of $\delta^{2} \mathrm{H}$ and $\delta^{18} \mathrm{O}$ in precipitation and shallow groundwater in the Hilly Loess Region of the Loess Plateau, China. Environmental Earth Sciences, 63(5): 1105-1118.

Liu, X. and Zhan, H., 2017. Calculation of Steady-State Evaporation for an Arbitrary Matric Potential at Bare Ground Surface, Water, 2017, 9(10): 729.

Ma, Y. and Song, X., 2016. Using stable isotopes to determine seasonal variations in water uptake of summer maize under different fertilization treatments. Science of The Total Environment, 550: 471-483.

Mahendrappa, M.K., Smith, R.L. and Christiansen, A.T., 1966. Nitrifying Organisms Affected by Climatic Region in Western United States. Soil Science Society of America Journal, 30(1): 60-62.

Merchán, D., Causapé, J. and Abrahão, R., 2013. Impact of irrigation implementation on hydrology and water quality in a small agricultural basin in Spain. Hydrological Sciences Journal, 58(7): 1400-1413.

Min, L., Shen, Y., Pei, H. and Wang, P., 2018. Water movement and solute transport in deep vadose zone under four irrigated agricultural land-use types in the North China Plain. Journal of Hydrology, 559: 510-522.

Nagaraj, N., 1999. Institutional management regimes for pricing of irrigation water: the French model lessons for India. Agricultural Systems, 61(3): 191-205.

Ochoa, C., Fernald, A.G., Guldan, S.J. and Shukla, M.K., 2007. Deep Percolation and its Effects on Shallow Groundwater Level Rise Following Flood Irrigation. 
Ochoa, C.G., Fernald, A.G., Guldan, S.J. and Shukla, M.K., 2009. Water Movement through a Shallow Vadose Zone: A Field Irrigation Experiment. Vadose Zone Journal, 8(2): 414-425.

Qian, H., Li, P., Wu, J. and Zhou, Y., 2012. Isotopic characteristics of precipitation, surface and ground waters in the Yinchuan Plain, Northwest China. Environmental Earth Sciences, 70.

Ren, D., Xu, X., Hao, Y. and Huang, G., 2016. Modeling and assessing field irrigation water use in a canal system of Hetao, upper Yellow River basin: Application to maize, sunflower and watermelon. Journal of Hydrology, 532: 122-139.

Robertson, J.A. and Gazis, C.A., 2006. An oxygen isotope study of seasonal trends in soil water fluxes at two sites along a climate gradient in Washington state (USA). Journal of Hydrology, 328(1): 375-387.

Rothfuss, Y. and Javaux, M., 2017. Reviews and syntheses: Isotopic approaches to quantify root water uptake: a review and comparison of methods. BIOGEOSCIENCES, 14(8): 2199-2224.

Scanlon, B.R. and Goldsmith, R.S., 1997. Field study of spatial variability in unsaturated flow beneath and adjacent to playas. Water Resources Research, 33(10): 2239-2252.

Scanlon, B. R., Jolly, I., Sophocleous, M., and Zhang, L. (2007), Global impacts of conversions from natural to agricultural ecosystems on water resources: Quantity versus quality, Water Resour. Res., 43, W03437, doi:10.1029/2006WR005486.

Scanlon, B.R., Reedy, R.C. and Tachovsky, J.A., 2007. Semiarid unsaturated zone chloride profiles: Archives of past land use change impacts on water resources in the southern High Plains, United States. Water Resources Research, 43(6).

Scanlon, B.R., Reedy, R.C., Stonestrom, D.A., Prudic, D.E. and Dennehy, K.F., 2005. Impact of land use and land cover change on groundwater recharge and quality in the southwestern US. Global Change Biology, 11(10): 1577-1593.

Song, X. et al., 2009. A study of soil water movement combining soil water potential with stable isotopes at two sites of shallow groundwater areas in the North China Plain. Hydrological Processes, 23(9): 1376-1388.

Sprenger, M. et al., 2018. Measuring and Modeling Stable Isotopes of Mobile and Bulk Soil Water. Vadose Zone Journal, 17(1): 170149.

Tan, H. et al., 2017. Stable isotopes of soil water: Implications for soil water and shallow groundwater recharge in hill and gully regions of the Loess Plateau, China. Agriculture, Ecosystems \& Environment, 243: $1-9$.

Teshome, Y., Biazin, B., Wolka, K. and Burka, A., 2018. Evaluating performance of traditional surface irrigation techniques in Cheleleka watershed in Central Rift Valley, Ethiopia. Applied Water Science, 8(8): 219 .

Van Genuchten, M.T., 1980. A closed-form equation for predicting the hydraulic conductivity of unsaturated soils. Soil Science Society of America Journal, 44(5): 892-898.

Wang, P., Song, X., Han, D., Zhang, Y. and Liu, X., 2010. A study of root water uptake of crops indicated by hydrogen and oxygen stable isotopes: A case in Shanxi Province, China. Agricultural Water Management, 97(3): 475-482.

Wang, P., Song, X., Han, D., Zhang, Y. and Zhang, B., 2012. Determination of evaporation, transpiration and deep percolation of summer corn and winter wheat after irrigation. Agricultural Water Management, 105: 32-37.

Wang, X. et al., 2019. Salt leaching of heavy coastal saline silty soil by controlling the soil matric potential. Soil and Water Research, 14: 132-137. 
Wei, J., 2013. The groundwater level dynamic effect factors and changing types of Yinchuan Plain. Ningxia Engineering Technology, 12(03): 209-211 (in Chinese with English abstract).

$\mathrm{Wu}$, X. et al., 2016. Optimizing conjunctive use of surface water and groundwater for irrigation to address human-nature water conflicts: A surrogate modeling approach. Agricultural Water Management, 163: 380392 .

$\mathrm{Xu}$, X. et al., 2013. Assessing the effects of water table depth on water use, soil salinity and wheat yield: Searching for a target depth for irrigated areas in the upper Yellow River basin. Agricultural Water Management, 125: 46-60.

Yang, L., Song, X. and Qiao, Y., 2018. Water Cycle Process Research: Experiments and Observations. In: Hydrology of Artificial and Controlled Experiments. IntechOpen, London, United Kindom, pp. 107-125.

Yang, L., Song, X., Ma, Y., Qiao, Y. and Chen, Q., 2014. An automatic tensiometer, 2014-4-9.

Zhang, P. et al., 2009. Spatial distribution pattern of soil salinity and saline soil in Yinchuan plain of China. Transactions of the CSAE, 25(07): 19-24.

Zhang, R., Qiao, Y. and Xue, J., 2015. Spatial relationship analysis between the soil salinization and land use intensity in Yinchuan Plain. Journal of Geo-information Science, 17(05): 598-606 (in Chinese with English abstract).

Zhao, X., Li, F., Ai, Z., Li, J. and Gu, C., 2018. Stable isotope evidences for identifying crop water uptake in a typical winter wheat-summer maize rotation field in the North China Plain. Science of The Total Environment, 618: 121-131.

Zheng, W., Wang, S., Sprenger, M., Liu, B. and Cao, J., 2019. Response of soil water movement and groundwater recharge to extreme precipitation in a headwater catchment in the North China Plain. Journal of Hydrology, 576: 466-477.

\section{Hosted file}

Figures.pdf available at https://authorea.com/users/346364/articles/540266-evaluatingperformance-of-soil-water-movement-and-groundwater-recharge-in-an-irrigatedagricultural-area-of-yinchuan-plain-china

\section{Hosted file}

Tables.docx available at https://authorea.com/users/346364/articles/540266-evaluatingperformance-of-soil-water-movement-and-groundwater-recharge-in-an-irrigatedagricultural-area-of-yinchuan-plain-china 